\title{
Microscopic appearance of healthy teeth, burned-tooth and automobile battery solution soaked tooth for the importance of visum in forensic dentistry
}

\author{
Randy Rozano*, Murnisari Dardjan*, Fahmi Oscandar** \\ *Department of Oral Biology Faculty of Dentistry Universitas Padjadjaran \\ **Department of Dentomaxillofacial Radiology Faculty of Dentistry Universitas \\ Padjadjaran
}

\begin{abstract}
Introduction: The hard tissue of the teeth is resistant to heat and acid, so that the teeth have an important role as a material consideration of forensic dentistry. The humans have the same shape of the teeth around one in two billion. The stimuli of burn with high temperature and sour can be change the picture of macroscopic and microscopic tooth. This is the subject of an interesting comparison in the interests of justice and identification of dentistry. Methods: This research was a quasi experiment to analyzed change of microscopic teeth on the hard cases tooth-burning and the case hard acid treatment. The sample used were seven teeth, with details of one normal as a comparison, three teeth burned and three teeth soaked in a solution of water of accu.. Observations were made using the microscope at 40x enlarged on each tooth. The tooth was documented by means of a photographed and compared with healthy teeth. Observing and comparing the microscopic structure and the obtained differences in the teeth and treated with the picture of normal teeth. Results: The results of this study was obtained by observing and comparing the microscopic structure and the obtaineddifferences in the teeth and treated with the picture of normal teeth. Conclusion: The tooth are burned was visible loss of enamel at the cement-enamel junction as a result of the process of carbonization heat exposure so as to cause a breach of micro on the outer layer of the tooth enamel and thinning of dentin tubules, while the teeth are in the soak water accu (strong acid) seen change in color of enamel, micro cracks due to defective enamel and depletion of tubulus dentine and loss of boundary between the cementum and dentine.
\end{abstract}

Keywords: Tooth, microscopic, heat, acid

\section{INTRODUCTION}

Teeth are the hard tissue that is resistant to heat and acid. Therefore teeth have an important role in forensic consideration. Forensic dentistry is basically the study of dental applications in legal proceedings. Forensic dentistry is a branch of dentistry that studies how to handle and examine evidence in the form of teeth used in the jurisdiction. Subjects cover a variety of topics including individual identification, mass identification, and bite mark analysis. ${ }^{1}$

Besides having strong defence against heat and acid, teeth have other advantages in forensic considerations, for example in the process of identification. Unique individual characteristics in the tooth structure and tooth restoration have the ability to identify with high accuracy. The 
characteristics of teeth in this world are different, so the possibility of humans having the same teeth is about one in two billion. ${ }^{2}$ Teeth can survive in hot temperatures between $400^{\circ} \mathrm{C}$ to $600^{\circ} \mathrm{C}$, so the teeth are the last part of the body that is destroyed in the combustion process. In addition, it is likely to break down even longer if there are metal dentures in the jaw. ${ }^{3}$

Besides having the ability to withstand high temperatures, the teeth turned out to be able to deal with strong acids, as evidenced in the "Haigh incident". Haigh killed his victims and then soaked them in a strong acidic liquid to dissolve their bodies including bones. But apparently the victims' teeth are still intact. ${ }^{4}$

Enamel together with dentin and cementum are hard tissues in the tooth structure. In humans, enamel thickness varies. The height of the tooth crown is thicker (approximately 2, $5 \mathrm{~mm}$ ) and the thinnest is at cementoenamel junction (CEJ). ${ }^{5}$ Tooth enamel is a protective structure that covers the outer portion of the dental crown. Dentin often called as Ivory which is a network under the tooth enamel. Dentin supports tooth enamel. ${ }^{6}$

Dentin consists of a number of micro-fibers that are embedded in a homogeneous matrix which is dense with collagen. The cementum is the part of the anatomy of the tooth that covers the outside of the dentin at the root (below the gum line) and the cementum attaches to the jaw bone with small elastic fibers. Cementum is harder than bone but not as hard as tooth enamel. ${ }^{6}$

Overview of Hard Tooth Network Structure The hard tissue in the teeth includes enamel, which is the hardest structure in the part of the teeth and also the hardest tissue in all human body tissues. ${ }^{6}$ Aim of this research is to analyzed microscopic picture of teeth in the state of exposure to high temperatures in combustion and also the teeth exposed to strong acid which is automobile battery solution.

\section{METHODS}

In this study, quasi experimental method is used that this research consists of one or several experimental groups and one control group. The group used was dependent variable that measured once which is after the experiment. The study was conducted in the Laboratory of Histology, Faculty of Medicine, University Padjadjaran and the research was conducted for 2 weeks.

The sample in this study were 7 premolar teeth within good health. Three premolar teeth was burned, three premolar teeth immersed in battery water, while one other premolar teeth as a comparison. The sample used in this study were healthy teeth with minimum plaque or caries.

The process of burning premolar teeth was carried out above the Bunsen burner with a temperature around $\pm 180^{\circ}-250^{\circ} \mathrm{C}$ for 30 minutes. Immersion of premolar teeth in the battery water with acidity $(\mathrm{pH})$ value of $0.6-0.8$ for 24 hours. Microscopic changes in the teeth were then analysed using a microscope.

\section{RESULTS}

Tabel 1. Category measurment sciences

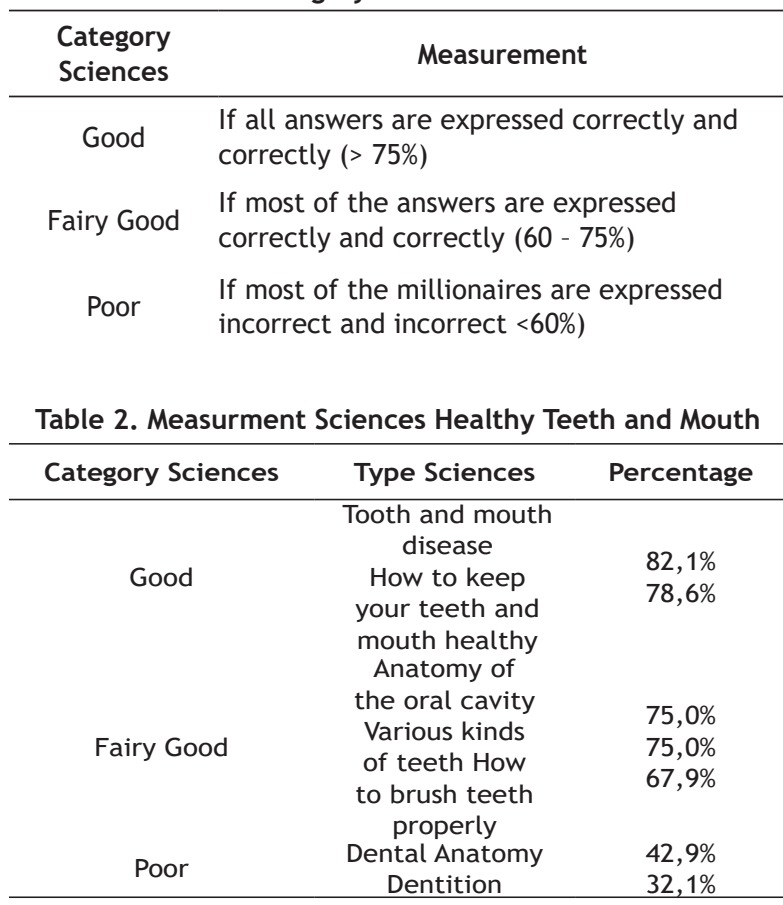

Table 3. Measurment Sciences about Anatomy Oral cavity

\begin{tabular}{ccc}
\multicolumn{3}{c}{ Oral cavity } \\
\hline Category & Type Sciences & Percentage \\
\hline \multirow{3}{*}{ Good } & Total adult teeth, & $100,0 \%$ \\
& Adult dental components & $96,4 \%$ \\
& & $92,9 \%$ \\
& Molar teeth grow to an & \\
& adult period Milk tooth & \\
Fairy Good & components The number & $75,0 \%$ \\
& of baby teeth First teeth & \\
& grow period teeth milk & \\
Poor & Teeth function & $35,7 \%$ \\
\hline \multicolumn{3}{c}{ First teeth grow period } \\
\end{tabular}


Padjadjaran Journal of Dentistry 2013;25(3):197-201.

Table 4. Meurment sciences about Anatomy teeth

\begin{tabular}{|c|c|c|}
\hline $\begin{array}{l}\text { Category } \\
\text { Sciences }\end{array}$ & Type Sciences & Percentage \\
\hline Good & $\begin{array}{c}\text { Total adult teeth, } \\
\text { Adult dental components }\end{array}$ & $\begin{array}{l}100,0 \% \\
96,4 \% \\
92,9 \% \\
92,9 \%\end{array}$ \\
\hline Fairy Good & $\begin{array}{l}\text { Molar teeth grow to an } \\
\text { adult period Milk tooth } \\
\text { components The number } \\
\text { of baby teeth First teeth } \\
\text { grow period teeth milk }\end{array}$ & $75,0 \%$ \\
\hline \multirow[t]{2}{*}{ Poor } & Teeth function & $35,7 \%$ \\
\hline & $\begin{array}{l}\text { First teeth grow period } \\
\text { teeth milk }\end{array}$ & $35,7 \%$ \\
\hline
\end{tabular}

Table 5. Measurment Sciences about mixed teeth

\begin{tabular}{ccc}
\hline Category & & \\
Sciences & Type Sciences & Percentage \\
& & \\
\hline & Explanation of incisors & $100,0 \%$ \\
& Overview of molars & $96,4 \%$ \\
Good & Overview of canine teeth & $92,9 \%$ \\
& Overview of incisors & $92,9 \%$ \\
& The function of molars & $89,3 \%$ \\
& Incisor function & $82,1 \%$ \\
& The function of canines & $82,1 \%$ \\
Fairy Good & & \\
& Explanation of molars & $42,9 \%$ \\
& Explanation of canine teeth & $39,3 \%$
\end{tabular}

Table 6. Measurment Sciences about teeth accretion

\begin{tabular}{|c|c|c|}
\hline $\begin{array}{l}\text { Category } \\
\text { Sciences }\end{array}$ & Type Sciences & Percentage \\
\hline Good & & $\begin{array}{c}100,0 \% \\
85,7 \%\end{array}$ \\
\hline Fairy Good & & $\begin{array}{l}57,1 \% \\
53,6 \% \\
42,9 \% \\
35,7 \%\end{array}$ \\
\hline
\end{tabular}

Table 7. asurment Sciences about teeth accretion

\begin{tabular}{ccc}
\hline $\begin{array}{c}\text { Category } \\
\text { Sciences }\end{array}$ & Type Sciences & Percentage \\
\hline Good & $\begin{array}{c}\text { Things to consider } \\
\text { in brushing your } \\
\text { teeth }\end{array}$ & $100,0 \%$ \\
& $\begin{array}{c}\text { The characteristics } \\
\text { of a good } \\
\text { toothbrush } \\
\text { The order in which } \\
\text { to brush your teeth }\end{array}$ & $100,0 \%$ \\
Fairy Good & Good dentifrice & $75,0 \%$ \\
& &
\end{tabular}

Table 8. Measurment Sciences about illness Teeth and Mouth

\begin{tabular}{|c|c|c|}
\hline $\begin{array}{l}\text { Category } \\
\text { Sciences }\end{array}$ & Type Sciences & Percentage \\
\hline Good & $\begin{array}{l}\text { Causes of gum } \\
\text { inflammation } \\
\text { Causes of tartar } \\
\text { occurrence } \\
\text { Causes of cavities } \\
\text { The Process of } \\
\text { Occurring Teeth }\end{array}$ & $\begin{array}{l}100,0 \% \\
100,0 \% \\
100,0 \% \\
78,6 \%\end{array}$ \\
\hline $\begin{array}{l}\text { Category } \\
\text { Sciences }\end{array}$ & Type Sciences & Percentage \\
\hline Good & $\begin{array}{l}\text { period brushing teeth } \\
\text { Food are good } \\
\text { Regular dentist's } \\
\text { examination }\end{array}$ & $\begin{array}{c}100,0 \% \\
100,0 \% \\
96,4 \%\end{array}$ \\
\hline Fairy Good & $\begin{array}{l}\text { Frequency of brushing } \\
\text { teeth Good habits }\end{array}$ & $\begin{array}{l}75,0 \% \\
67,9 \%\end{array}$ \\
\hline
\end{tabular}

Enamel, dentin and cementum are semitranslucent, so they can be seen under the microscope, while in soft tissue is radiolucent. ${ }^{6}$

\section{DISCUSSION}

Teeth are more resistant and not easily damaged due to environmental factors, such as high temperatures or acidic conditions. This can be proven by the many fossils of living creatures in the past whose jaw and tooth conditions are still intact today. Teeth are also very resistant to heat. Teeth remain intact at high temperatures, even though the body has been damaged, but the teeth can still be identified.

Macroscopically, burnt teeth do not have significant changes in tooth shape. But there will be some changes in color due to the carbonization process on the tooth surface. In addition, teeth look very fragile and more difficult to be destroyed in the area that affected by the heat exposure than areas that are less exposed to heat. After the teeth were grinded and ground, the teeth were placed on a glass and viewed under the microscope.

The teeth were soaked in the automobile battery solution (acidic solution) in this experiment for a day to see the changes of the microscopic structure. Macroscopically, teeth that have been soaked in the solution for 24 hours have several 
changes. Chalky white can be seen on the surface of hard tissue which is enamel and cementum that directly in contact with battery solution. This causes teeth to become very fragile.

Teeth are grinded using a burnisher because the teeth are very easily to be destroyed. Not only the surface of the teeth became weakened, but also into the teeth which is dentin, so the teeth must be grinded again using fine sandpaper. After the teeth are smooth enough, the teeth are placed in a glass object and viewed for the microscopic appearance.

The following is the picture of teeth that have been burned and soaked in the battery solution microscopically and compared with the normal teeth. Macroscopically, the enamel surface looks very fragile after the teeth were burned and when the teeth are soaked in the battery solution, it was easily destroyed and very easy for cutting. Microscopically, the burned teeth carbonized due to combustion.

There are cracks that are caused by a fairly hot temperature on the teeth. These cracks are in areas where heat exposure is higher than other areas of the tooth. When it was burning, carbonization received by the enamel due to heat exposure and changes the colour of the enamel so that it looks scorched.

For battery solution soaked teeth, the enamel surface of the tooth that soaked looks blurred. This is due to the structure of the enamel became weakened and change the original color of the enamel. The chalky white of teeth due to the battery solution which is strong acid is due to the porosity on the surface of the enamel. For teeth exposed to strong acids, there will be an enlarged micro crack which caused by the strong acid. This chalky white surface of the tooth is due to erosion that occurs on the enamel because of long duration in contact with strong acids.

The process of tooth erosion begins with the release of calcium in enamel, and this process happens continuously until the loss of some elements of the enamel. Given that calcium is a major component in tooth structure, and enamel demineralization occurs due to the release of calcium ions from tooth enamel, the effect of acid on tooth enamel is a decomposition reaction. Continuous demineralization will form small pores or porosity on the enamel surface that did not exist previously. Each enamel will have dentin underneath and so far cracks in the enamel (crazes) penetrate into dentin only from this study. The cracks from the enamel surface due to the influence of strong acids. Extreme fragility and small enamel fragments may make the assessment of colour very difficult when compared to all dentin specimens so that the boundary between enamel and dentin is difficult to determine. Therefore the color of the enamel and dentin fused so that the boundaries of the dentine tubules are difficult to see.

For battery solution soaked- teeth, the process occurs further due to acid, tooth erosion occurs even though the erosion process in dentin is not as fast as in the enamel. The tubule dentin in the affected teeth appears thinner. This is due to the process which apparently also affects the tubule dentin. The surface of the teeth that soaked in the battery solution, CEJ looks very thin due to erosion process. Besides that, the boundary between cementum and CEJ is also missing. On the surface of the cementum that was exposed, there is carbonization which thinned the outermost structure of the cementum.

As a result of exposure to heat, cementum which are not as thick as enamel undergo very heavy carbonization, especially on the surface of cementum, so that cementum on burned teeth experiences thinning and also loss of the outer portion due to this heat exposure.

The outer surface of the cementum looks eroded due to the direct effect of the battery solution. This thinning causes the root surface fragile, but the boundary between cementum and dentin is very clearly seen in teeth exposed to battery solution.

\section{CONCLUSION}

The tooth are burned was visible loss of enamel at the cement-enamel junction as a result of the process of carbonization heat exposure so as to cause a breach of micro on the outer layer of the tooth enamel and thinning of dentin tubules, while the teeth are in the soak water accu (strong acid) seen change in color of enamel, micro cracks due to defective enamel and depletion of tubulus dentine and loss of boundary between the cementum and dentine. 


\section{REFERENCES}

1. Schuurs AHB. Patologi Gigi Gigi : Kelainan jaringan keras gigi. a Yogyakarta : Gajah Mada University Press. 1992

2. Suwelo IS. Peranan pelayanan kesehatan gigi anak dalam menunjang kualitas sumber daya manusia Indonesia di masa mendatang. Jakata : Universitas Indonesia. 1997.

3. Dewanti. Hubungan Tingkat Pengetahuan tentang Kesehatan Gigi dengan Perilaku Perawatan Gigi pada Anak Usia Sekolah di SDN Pondok Cina 4 Depok. Depok : Universitas Indonesia. 2012.

4. Astoeti, Tri Erri. Pendidikan Kesehatan Gigi di Sekolah. Jakarta : PT. Rajagrafindo Persada. 2006.

5. Putri, Indah N. Efek Penyuluhan Kesehatan Gigi Dan Mulut Dengan Demonstrasi Cara Menyikat Gigi Terhadap Penurunan Indeks Plak Pada
Murid Kelas Vi Sekolah Dasar (Penenelitian Dilakukan Di Desa Padang Loang Kecamatan Patampanua Kabupaten Pinrang). Makasar : Universitas Hasanudin. 2012

6. Ghofur, Abdul. Buku Pintar Kesehatan Gigi dan Mulut. Yogyakarta : MITRA BUKU. 2012.

7. Syamsyudin, Abin. Psikologi Pendidikan. Bandung : PT. Remaja Rosda Karya. 2003.

8. Hutabarat, Natalina. Peran Petugas Kesehatan, Guru, dan Orang tua dalam Pemeliharaan UKGS dengan Tindakan Pemelihraan Kesehatan Gigi dan Mulut Murid Sekolah Dasar di Kota Medan. Medan : Universitas Smatra Utara. 2009.

9. Kementrian Kesehatan RI. Rencana Program Pelayanan Kesehatan Gigi dan Mulut. Jakarta. 2012

10. Basir, Ika Ariyani. Gambaran Pengetahuan Dan Sikap Guru Penjaskes Berbasis Ukgs Dan Non Ukgs Di SDN Kota Makassar. Makasar : Universitas Hasanudin. 2011 